\title{
The Research on Art Design Teaching Management System Based on WEB: An Exploratory Study
}

\author{
Haixiang $\mathrm{LI}^{1, \mathrm{a}}$ \\ ${ }^{1}$ School of Art,Henan Institute of Education, Zhengzhou 450046, China \\ ahaixiangli@126.com
}

Keywords: Art Design, ASP.NET, Web, Management System

\begin{abstract}
Computer information technology to the life of people brought a historical leap and change, change the teaching methods of modern education and student learning. Teaching management is the core content of school management, with the expansion of colleges and universities, the increase in the number of students, the course of add, its complexity and comprehensive modernization of management, teaching management system based on WEB is the important way of modern teaching management informatization. This paper puts forward the design of art design teaching management system based on WEB was studied, can make full use of modern Internet technology and network resources, promote the work of art design teaching management and quick operation, realize the maximum utilization of teaching resources, has very important practical significance.
\end{abstract}

\section{Introduction}

Teaching work is the core of school work, teaching management is the very focus of work in school management, improve the quality of teaching for students majoring in arts design, specification of art teaching order, to ensure the normal order of the professional art teaching work orderly. Course for students majoring in arts design has bigger difference compared with the traditional course, in the artistic design specialized courses often contain a lot of teaching material, student work is also very huge amount of information, and these materials are stored in the form of pictures or files before encoded music and computer hard disk [1-3]. In order to present good effect, the material usually take a lot of storage space, may cause data loss because of the hard disk is lost or broken, it is also possible for virus reason lead to all information cannot be read. It is because of the characteristic, to art and design professional curriculum resources management and sharing, and student work save file caused greater difficulties.

Compared with traditional teaching mode, with the development of the individualized teaching, network teaching is no longer restricted by time and space as the traditional teaching, at the same time, the network teaching can make to get a bigger share of teaching resources, and greatly reduce the cost of education, embodies the popularization of education, the ultimate goal of lifelong, diversification and internationalization.

Now the world, the tide of global information electronically as unstoppable as flood also. Computer information technology to the life of people brought a historical leap and change. Computer information technology not only changed the current form of people's work and way of life, has also changed the teaching methods of modern education and student learning. At present, many foreign colleges and universities have developed a teaching management system based on WEB [4]. Combining with the actual situation, study of art and design professional curriculum resources characteristics, and from the accumulation of curriculum resources, teaching resources show exchange and sharing resources, teachers and students, students' homework collection and so on several aspects of research [5]. Both for comprehensive for art design specialty teaching management, data collection, understanding of the arts students comprehensive information provides a convenient, sorting data, student work and its result is more accurate and convenient query statistics, also can use electronic data step by step instead of the traditional paper and CD-ROM data, modernization of teaching management. 


\section{Development environment and related technologies}

Any software development, the choice of development environment is very important, because the appropriate development environment can greatly reduce the workload of system development, at the same time to keep the system has the best performance and system maintenance work is also very easy in the future. So before the development of art design teaching management system, needs the system USES for the technology, realize the function of proper evaluation, any software development, in the choice of system development environment are factors to consider are: the total cost and scalability, software function, these factors are easy to development and management, at the same time, the openness and interoperability of systems in the development of art design teaching management system is a very important aspect, because art design teaching management system is running on the Web, the final system difference determines the interoperability with other systems.

ASP.NET is the most popular a unified Web development model, it includes generating a variety of services necessary to an enterprise Web application, and it use the code number of the least, as the technology architecture to ASP.NET as in Figure 1. Part of the.net Framework structure Framework. So programmers to write ASP.NET application code, you can access [6-7]. Any classes in the.net Framework can be used in any language compatible with the common language runtime to write the program, as a result, relative to simplify program design, the structure is very clear and application performance, scalability, and security is also very strong. It can also use ADO.NET technology is very convenient to access the database, the data of the operation more convenient and flexible.

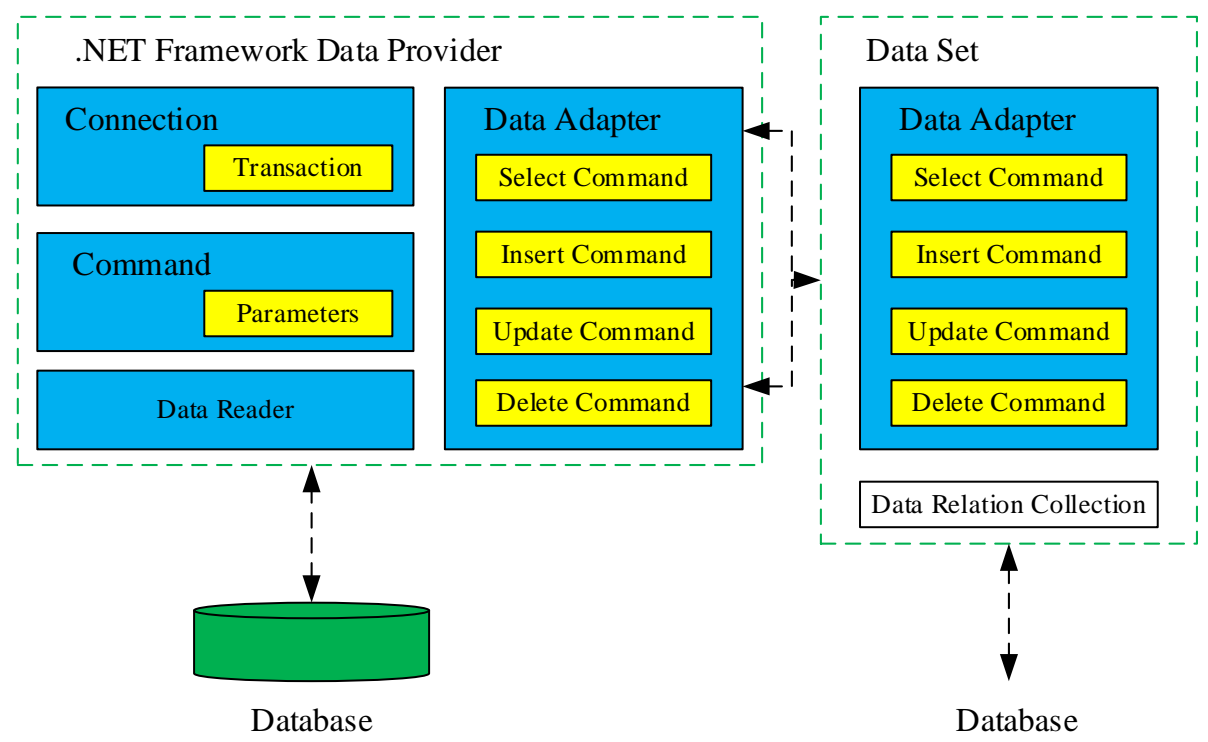

Figure 1. System structure of ADO.Net

ASP.NET is only part of the.net Framework structure. Including provided with the.Net Framework structure framework to access the database, it connects to the Internet, security. Due to ASP.NET will be able to use the.net Framework all of these features, so compared with the previous Web application, ASP.NET will be able to build very rich Web applications. And ASP.NET is in the time needed for building Web applications with very little, the programmer can focus all your energy and time on the application of special logic. ASP.NET will also.net Framework structure is introduced as a Framework of Web programming to come in, so that you can in a typical dynamic server page greatly improved the development mode and development efficiency. 


\section{Function analysis of colleges' art design teaching management system}

As the function structure of colleges' art design teaching management system is shown in figure 2 . According to the analysis of art and design teaching management system, combining with the experience and feeling, in the actual development of art design teaching management system, the following principles should be adopted to guarantee to achieve the purpose of computer network management.

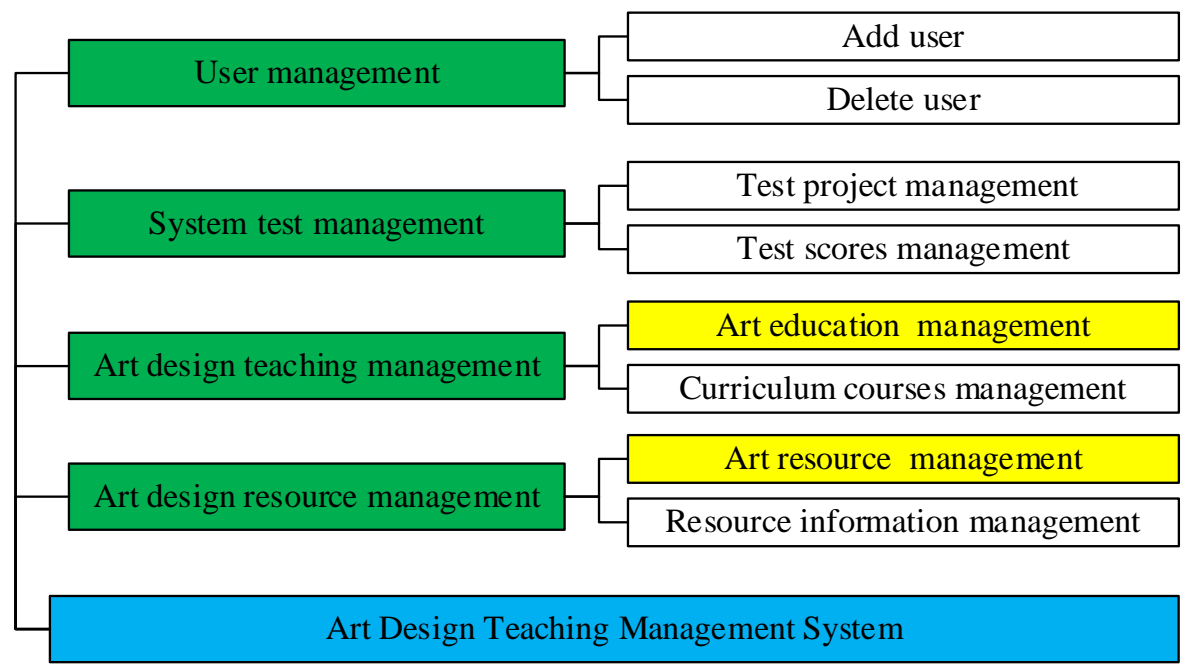

Figure 2. Function structure of colleges’ art design teaching management system

1. High maintainability. Arts teaching management system in teaching management plays a very important role in the process of management, must be achieved in the software configuration management and maintenance is simple, highly concentrated and efficient to the extreme, not because of system maintenance issues, such as virus or hacker intrusion makes art design teaching management system cannot run normally, art discipline teaching management effect of stagnation.

2. High reusability. In the arts teaching management system of the design process, should fully consider the user's existing human-computer interaction and daily habits, reduce the training and learn to use the system in terms of the investment of time and energy, make the arts teaching management system can quickly put into use and good operation, play the effect of its artistic discipline and teaching management.

3. High security. A lot of information in the arts teaching management is relatively confidential information, privacy, needs to be stored safely and reliably and transmission and sharing of resources. High security art design teaching management system should therefore displays in: does the effective protection of information is not easily exposed to unauthorized user or process. For each user to define the respective management area, in the isolated state, make each region can only manage this area of the teaching management.

4. The stability and reliability. In art design teaching management system to store the basic information of the teaching management, student information, performance information, teacher information important data, such as system reliable and stable, it must be guaranteed. For art design teaching management system and user, the most important is that these data and information, in use process should be timely backup storage of information, so that in case of emergency can quickly return to the front of the collapsed state, ensure the effective sustainability in work.

5. Hierarchical modular design. Art design teaching management system should be in accordance with the principle of hierarchical modular design to design the system. Functional modules, hierarchical and interface between art and design teaching management system to be clear, try our best to reduce between modules, level and the degree of coupling between art and design teaching management system. By adopting the combination of computer and C/S mode way to complete software development, meet the art design teaching management system is reliable and easy to use, available, and extensible. 


\section{Overall design of colleges’ art design teaching management system}

Art and design teaching system using a modular design approach for data center connections between modules, the system according to the function is divided into different modules, each module and segment top-down functional decomposition. The whole system is based on a data processing center, at the same time, taking into account the data transmission between the cohesion and the coupling module, the database module of the system data center, thereby improving the independence between the modules to enhance the scalability of the system. Systems Application Architecture program refers to the process of construction of the entire system. Application system architecture is divided into three layers, namely, the presentation layer, business layer and access layer, application support. Close ties between the three, the interaction between users. System application architecture shown in Figure 3.
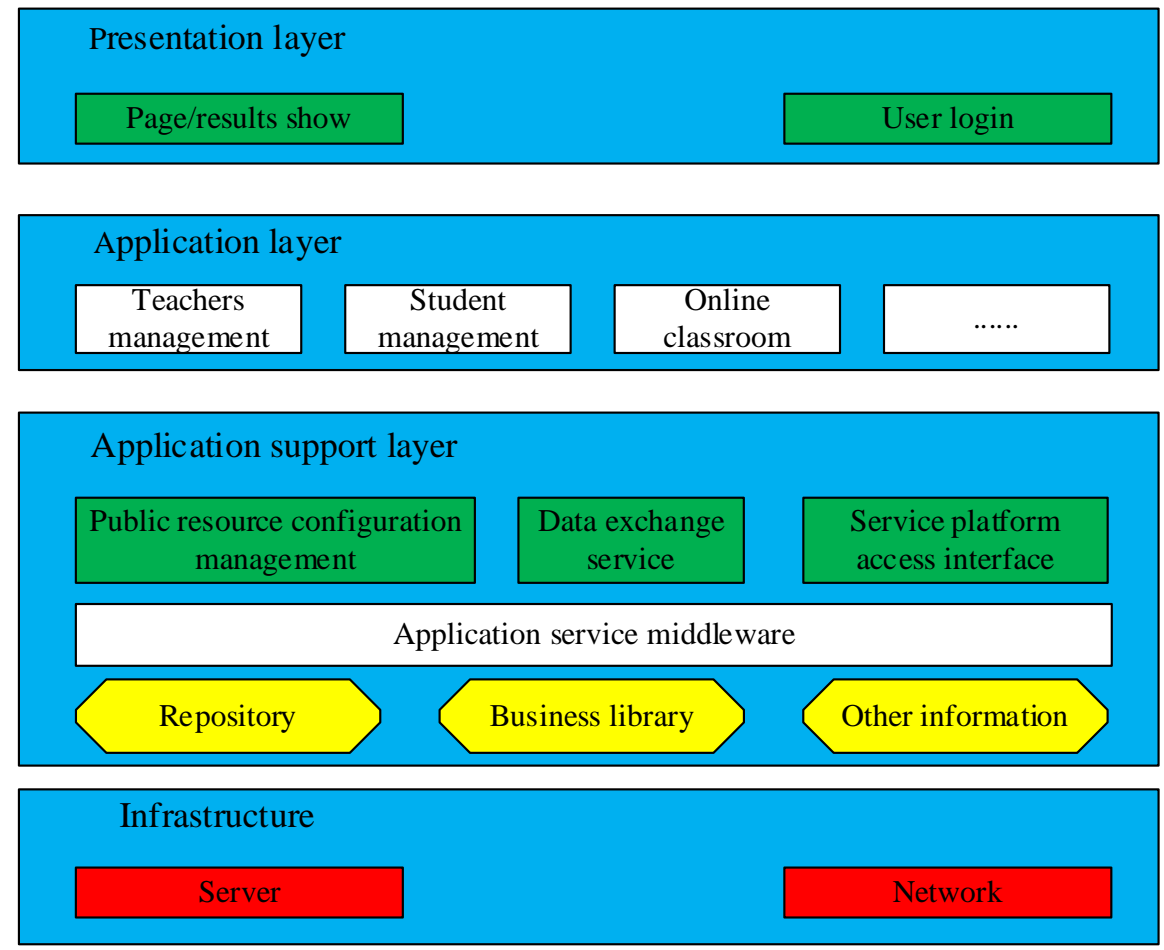

Figure 3. Overall structure of colleges’ art design teaching management system

Presentation layer. It refers to receive / display user information interface, users can take advantage of a layer of data input and display. Taking into account the system's user-friendly, web-based solution that this article will be implemented page presentation layer of the system. Application layer, enabling user access, login, authentication, information dissemination, and other functions.

Application layer. The main function of the application is to realize the development of business rules and business processes. Three-tier application architecture design, allowing users to avoid direct interaction with the database, business rules, data access, business logic layer to complete the data to check the legality of the work, from user interaction logic layer, thereby increasing the program's portability and scalability. Application layer can achieve teaching management information release system, teacher management, student management, online courses, systems management, and other functions, to achieve interact with databases.

Application support layer. Application support layer to integrate various resources, while providing a wide range of skills for the application layer. Application support layer can achieve security certification, public resources management, data exchange services and platform access interface. Through this layer to access the database at the same time, update the database, modify, delete, and query operations. Application support layer provides support for the business layer data 
alone is responsible for the maintenance and modification of data in order to improve the efficiency of data processing.

\section{Conclusion}

Teaching management is the core content of school management, with the expansion of colleges and universities, the increase in the number of students, the course of add, its complexity and comprehensive modern management means. In the information age today, the traditional management method has been based on computer information management system replaced. With the expansion of colleges and universities, the number of students increased, add the original teaching reflect its inefficiency, personnel management system is more and more tired, the disadvantages of resources waste, therefore put forward the art design teaching management system based on WEB design and implementation of the subject, promote the quick work of the art design teaching management, realize the maximum utilization of teaching resources, is the realization of a management system application modern education technology, has very important practical significance.

\section{References}

[1] Martins L L, Kellermanns F W. A model of business school students' acceptance of a web-based course management system[J]. Academy of Management Learning \& Education, 2004, 3(1): 7-26.

[2] Wang Q, Woo H L, Quek C L, et al. Using the Facebook group as a learning management system: An exploratory study[J]. British Journal of Educational Technology, 2012, 43(3): 428-438.

[3] Su A Y S, Yang S J H, Hwang W Y, et al. A Web 2.0-based collaborative annotation system for enhancing knowledge sharing in collaborative learning environments[J]. Computers \& Education, 2010, 55(2): 752-766.

[4] Wu Y C J, Huang S, Kuo L, et al. Management education for sustainability: A web-based content analysis[J]. Academy of Management Learning \& Education, 2010, 9(3): 520-531.

[5] Gaeta M, Orciuoli F, Ritrovato P. Advanced ontology management system for personalised e-Learning[J]. Knowledge-Based Systems, 2009, 22(4): 292-301.

[6] Popescu E. Adaptation provisioning with respect to learning styles in a Web - based educational system: an experimental study[J]. Journal of Computer Assisted Learning, 2010, 26(4): 243-257.

[7] Hemmerich C, Buechlein A, Podicheti R, et al. An Ergatis-based prokaryotic genome annotation web server[J]. Bioinformatics, 2010, 26(8): 1122-1124. 